\title{
AN OVERVIEW OF THE POLICIES OF THE WEST, HUMAN RIGHTS AND THE ISLAMIC WORLD
}

\author{
Dr. Abdul Khaliq \\ Assistant Professor ( Islamiat), Govt College of Technology Bahawalpur \\ Dr Muhammad Muavia Khan \\ Visiting lecturer at The Islamia University of Bahawalpur \\ ORCid: https://orcid.org/0000-0003-1518-3789 \\ Dr Muhammad Sajjad \\ Lecturer, The Best College Bahawalpur \\ ORCid:https://orcid.org/0000-0002-0883-5913
}

Article DOI: $\underline{\text { https://doi.org/10.36713/epra5964 }}$

\begin{abstract}
The twentieth century is a century of mind-boggling scientific inventions, unparalleled feats of scientific research and discovery. The rapid development of human civilization and the sciences and arts that have taken place during each decade of this century is even greater than the collective development of the entire period of known human history. But if we look at the pace of political and moral development, the enlightened unipolar world that has reached the threshold of the 21st century still seems to be trapped in the colonial darkness of the eighteenth and nineteenth centuries. Freedom, Equality, Democracy and Basic Human Rights have not been able to eradicate the blackness of the huge offices, the horrors of barbarism, oppression and injustice, aggression and cruelty. Under the weight of oppression, humanity is still wounded by the devil. Scientific inventions have bridged the gap between time and space and given the world the shape of a "human settlement", but alas! Couldn't bridge the gap between human hearts. That is why this "global settlement" is practically no different from a traditional settlement, it also has elders occupying power and resources and there are still losers drowning in the depths of humiliation. Blinded by the arrogance of scientific progress, the world may have subjugated the weak peasants whenever it wanted, but there is no one to stop its oppressive hands.
\end{abstract}

KEY WORDS: The West, America, Islam, Human rights, United nations 


\section{INTRODUCTION AND ANALYSIS}

If Anyone look at the conclusions drawn in the above lines in the context of the recent unjustified provocative and brutal aggression against Iraq, you will see that it is not a manifestation of any quintessential thinking but a realistic portrayal of the naked realities from which the international community The Muslim world in general is particularly affected. The AngloAmerican colonial dance of the Devil in the night darkness of missiles and barbaric bombardment on the unarmed people of Iraq between December 16 and December 19, 1998, has once again revived the fears of the Soviet Union. Born after the fall of America's unipolar status.

History has shown that imperialism has always carried out its imperialist aggressive ambitions under the guise of deception. Britain, France, the Netherlands, Germany and other European nations enslaved African and Asian nations and plundered them, but they always considered the subjugated masses a "white man's burden." In order to teach civilization to "uncivilized" nations, it is necessary to enslave them. As if colonial exploitation was no less than a "great favor" to these nations. The most intelligent philosophers and rulers of modern Europe have piled up arguments to justify European colonialism. John Locke and John Stuart Mill, without whose mention the European hymns of freedom, equality and human dignity are considered incomplete, considered the conquests of African and Asian nations at the hands of British imperialism to be essential to the cultural development of subjugated nations. Diya and wrote long essays in this regard. Today, the United States, the greatest champion of human rights and liberal democracy, always finds some beautiful justification for its barbaric and aggressive activities. That is why, after the 1991 Gulf War, former US President Richard Nixon brazenly claimed:

"The United States will never defend a goal with its own life that it cannot defend with its conscience. ${ }^{1}$

If the late Richard Nixon had been alive, the latest joint US-British invasion of Iraq would have been justified in order to satisfy his conscience. Before the 1991 Gulf War, the United States was responsible for its inhumane acts. There must have been a "problem" of stamping UN resolutions. At that time, it was not long before he rose to the position of a unipolar superpower. The negative effects of Sardajang's bitter experiences still lingered. That is why the United States had to paint its barbarism as a joint operation. Then the

${ }^{1}$ Richard Nixon: "Beyound Peace" Random House, Newyork 1994. (P.38) military occupation of Kuwait by Iraqi President Saddam Hussein in 1991 provided a very simple and reasonable excuse for the Gulf War, although later events $\mathrm{He}$ asserted that the United States was behind Saddam Hussein's assassination.

But suddenly and unexpectedly, in the night of December 16-17, in 1998, in the name of Operation Desert Fox, the United States and Britain rained missiles on Iraq. This time the resolution was passed by the Security Council, nor did it feel the need to take its permanent members into confidence. This time, Saddam Hussein's "unforgivable crime" was simply that he refused to cooperate with $\mathrm{UN}$ inspectors because he thought he was involved in the heinous crime and conspiracy of espionage under the guise of "inspection". To satisfy their conscience and to maintain their democratic credentials in the world, American colonialism this time relied on the straw of the report of Richard Butler, the head of the UN inspection team. Subsequent events proved that Richard Butler was pursuing a US agenda rather than the United Nations, and that US intelligence officials, along with members of his team, were engaged in covert intelligence missions. This has also been openly acknowledged by the American press.

Spying behind the scenes of the United Nations

What was special about this report ... The words "time" are:

"It showed that the Iraqis were using their usual tactics, such as concealing equipment that could be used to make biological weapons, obstructing meetings with workers at suspicious locations, and the use of chemical weapons in the past." Misrepresentation of sealed documents ..."

The Economist, a leading London-based weekly, also described Richard Butler's report as "unsatisfactory" in its "Lead Story" of 19 December 1998.

Satan the Great was looking for an excuse to express his devilishness

Khoy Badr Abhana very much. Otherwise, there were no serious complaints in this report. According to General Aslam Baig:

"There is a limit to fraud and coercion. The United States itself has acted as a judge and has decided to oust the arrogant Saddam himself" (2).

The seven-day "Time" has published a detailed article on the subject, entitled "Bugging Saddam." It is not difficult to gauge from the following quotations how ugly and vile American colonialism under the umbrella of the United Nations has been in carrying out its nefarious intentions against an independent state:

2 The Economist: Jan. 9, 1999 “Gun boat Diplomacy” (P.4) 


\section{SJIF Impact Factor: 7.001| ISI I.F.Value:1.241| Journal DOI: 10.36713/epra2016 ISSN: 2455-7838(Online) EPRA International Journal of Research and Development (IJRD)}

"For many years now, the Iraqi dictator has been insisting that UN inspectors who have come to his country to search for secret weapons are CIA agents working for Washington. U.S. spies have used Unscom, a supposed UN impartial commission, to gather deadly information about Saddam Hussein. U.S. officials responded immediately: "We may have been spying, but we did it just to help the United Nations."

Unscom was set up as a result of an agreement to end the Gulf War in 1991. Its mission was simple: to verify the destruction of Saddam's remaining missile, chemical and biological weapons capabilities. A senior White House official explained that Unscom's sole purpose was to spy on Iraq. "( $\left.{ }^{3}\right)$

... "US officials acknowledge that the National Security Agency and the CIA's Bug-Lets recorded information that could have been used to bomb Saddam's security team and potential targets." $\left({ }^{4}\right)$

The above report of Time has published detailed information about the types of spy devices, their installation locations, their constant communication with the headquarters, their automated spy network, etc. Similar reports have been published by The Economist (5), The Washington Post (6), The New York Times $\left({ }^{7}\right)$ and Newsweek.

Can an independent, sovereign state allow such heinous acts against its integrity within its borders? In the light of which code of conduct, international law or the UN Charter, was the Iraqi protest rejected and punished for an uncommitted sin?

\section{The real stimuli}

Dear readers! From the above, it is clear that Iraq's alleged arrogance or non-cooperation is just an excuse. Richard Butler's biased and espionage report has also failed to provide any living material to justify the rain of fire and iron on the Iraqi people. These are just hypocritical rhetoric and dictatorial maneuvers, there are other motives behind this unwarranted aggression which the imperialist propaganda machine has failed to hide in spite of all its media power. Neutral, conscientious intellectuals are pointing out these motives in clear words. It is necessary to mention here these nefarious intentions and motives.

(1) All industrial and scientific development in the developed countries of the United States and Europe

\footnotetext{
3 Bugging Saddam” Time: Jan. 18, 1999.

${ }^{4}$ IBID Page 32, 33

${ }^{5}$ The Economist: Jan. 9, 1999 (P.35)

${ }^{6}$ The Washington Post: Jan. 6, 1999

${ }^{7}$ N.Y. Time Jan. 7, 1999
}

depends on access to oil resources and uninterrupted supply of crude oil. That is why the Muslim Gulf states, which are rich in oil reserves in the Middle East, have been the focal point of the foreign policy of the Western imperialist powers and the cause of their extraordinary attention. Ensuring compliance with US intentions in matters such as oil production, pricing and uninterrupted free delivery has been a key goal of US foreign policy. Walter Russell Mead, the author of several books on US foreign policy, writes in his recent article:

"Oil is undoubtedly the main point of this whole affair. It is our need for oil that keeps the United States so deeply entangled in the complexities of the Gulf." India's status as that of the British Empire It is at the same time the cornerstone for American power, and the wounded heel for its global position (Achilles Heel), especially the oil-rich Persian Gulf states. Allied to Saudi Arabia, the United Arab Emirates, and Kuwait, the United States must protect those states from invasion by powerful neighbors, such as Iran and Iraq. The expansion of work, agreements, political relations, the deployment of troops all over the Middle East and its environs make such measures inevitable "( $\left.{ }^{8}\right)$.

Since the 1991 Gulf War, the United States has been actively occupying the oil reserves of the Gulf states without their participation. Exactly seven years after the Gulf War, the US economy has grown to such an extent that, according to economists, the US economy has not seen such prosperity in the last fifty years. The US budget for 1998/1999 is a surplus of 75 billion. In fact, it is the result of the "blessings" of the Gulf War. The United States has received trillions of dollars in "war expenses" from Saudi Arabia, Kuwait and the United Arab Emirates since the Gulf War. It has also saved trillions of dollars in additional costs over the past seven years as a result of purchasing cheap oil. It should be noted that the price of oil was 14 per barrel in 1974, 22 per barrel in 1991 and only 10 dollar per barrel in 1999. In contrast, the Gulf states are facing a severe economic crisis. Saudi Arabia and other Gulf states have been indirectly talking about the withdrawal of US troops. The United States wants to show them the wind of Saddam Hussein and blow their minds and shake their nerves with the deadly demonstrations of its tyrannical power. Some analysts see the recent American barbarism in this context.

\footnotetext{
${ }^{8}$ Walter Ressell Mead: “A Fading Coalition on Iraq", The

Los Angeles Times, Dec. 20, (Reproduced by the Friday

Times, Lahore: Dec. 25. 1998.)
} 


\section{SJIF Impact Factor: 7.001| ISI I.F.Value:1.241| Journal DOI: 10.36713/epra2016 ISSN: 2455-7838(Online) EPRA International Journal of Research and Development (IJRD)}

A majority of analysts said that the immediate reason for the above order of US President Bill Clinton was to divert attention from the impeachment motion against him. The American people themselves, as well as Republican leaders, reacted by saying, "The invasion of Iraq is part of a well-thought-out plan for the impeachment of President Clinton." The columnist for the weekly "Time" is as follows:

"It wasn't just Republicans who believed that Clinton had ordered the attack as an attempt to avoid impeachment in an effort like Wag the Dog. The same idea was echoed in the British Parliament and in the French press. During the demonstration in front of Cairo's Grand Mosque, a placard was waved - "Iraqi children are being killed for Monica" $\left({ }^{9}\right)$.

There was an American film called Wag the Dog, which told the story of an American president who unjustifiably attacked another country to save himself from a sex scandal and to divert public attention.

No matter how much President Bill Clinton and White House spokesmen deny the above interpretation, the impeachment motion and the proximity of the time of the invasion of Iraq make this argument seem plausible and can be accepted as an immediate impetus to the invasion. General Aslam Baig also wrote in support of the idea that "the Iraqi people have been drenched in blood over a naughty woman. It is certainly an unforgivable crime and the whole of humanity is lamenting over it." (10)

(3) According to Raqim al-Huroof, one of the immediate causes of the US aggression on December 16 could be President Clinton's attempt to gain the favor of the Jewish lobby and restore trust with Israel. The majority opinion is that the Monica scandal is the result of a conspiracy by the Jewish lobby. When Bill Clinton called on the Israeli government to eliminate Jewish settlements in the West and the cold-blooded attitude in the White House during Israeli Prime Minister Netanyahu's visit. Adopted, the influential Jewish lobby pushed the Monica scandal to teach Bill Clinton a lesson. The American media is Jewish-owned or at least influenced by them. He fanatically publicized the sex scandal. The fact that the majority of critics of Kenneth Starr, Monica Lewinsky and Bill Clinton are Jewish is not a good coincidence. It is difficult, if not impossible, for a US president to remain in the White House without the support of the Jewish lobby. President Bill Clinton soon realized this fact.

\footnotetext{
${ }^{9}$ What Good did it do" Time: Dec. 28, 1998 (P.22)

10 جGeneral Aslam Baig, America ki Andhi Taqleed ki

Cheera Dastyan, Daily Jang Lahore, December, 28, 1998
}

President Bill Clinton was visiting Israel three days before the US invasion of Iraq. According to Time, he was in Jerusalem on Sunday, December 13, when President Bill Clinton was notified of Butler's report. There, he gave the Pentagon 72 hours to prepare for the attack. "(11) According to the same weekly, on Tuesday morning, December 15, shortly after returning from the Middle East, President Clinton, along with his military advisers and vice president, considered the Butler report. Bill Clinton had made the final decision on the invasion of Iraq during his visit to Jerusalem. The meeting was convened only to take action and to take his close government members into confidence.

The Jewish control of the American financial system and media does not need to be explained. It was not until Richard Butler's report that the Jewish media had launched a storm of poisonous propaganda against Iraq to pave the way for a December 16 attack.

It is also noteworthy that after the US invasion of Iraq, the Zionist media began to create an atmosphere in favor of Bill Clinton and began to criticize those members of the Republicans who succeeded in impeachment motion against him. Were struggling to do. Finally, on January 12, 1999, the US Senate honorably acquitted President Bill Clinton. The news was prominently featured in Pakistani newspapers on January 13, 1999. Now the American press is taking good news of Clinton's opponents.

(4) The history of the American nation is not very old. The majority of today's white American ancestors were fugitives and savage merchants from various European countries. The history of the American nation began with the genocide of the local "Red Indians" and the rebellion of the motherland against England. Horror and barbarism are part of the collective mood of the American people. When power and wealth exceed a certain limit, it always takes the form of oppression. That is why the American people are sick of killing another nation.

(5) The United States has used Iraq as a training ground to satisfy its false dignity. The self of the American nation, according to Allama Iqbal, is a preverted ego. He believed that the riots began with Luther's religious reform movement in Europe, in which the universal morality of Christianity was ousted by national morality. $\left({ }^{12}\right)$ This motivation is also important behind the American atrocities. Because if the self of this

\footnotetext{
${ }^{11}$ Time Dec. 28, 1998 (P.23)

12 The Reconstruction of Religious Thought in Islam" hy Dr.

Muhammad Iqbal
} 


\section{SJIF Impact Factor: 7.001| ISI I.F.Value:1.241| Journal DOI: 10.36713/epra2016 ISSN: 2455-7838(Online) EPRA International Journal of Research and Development (IJRD)}

nation is not riot-ridden, other motives could never take a dangerous turn.

UN resolutions and international law

The joint US-British bombing of Iraq is a clear violation of international law, a gross disregard for UN resolutions, and the worst interference in the internal and external sovereignty of a free and independent state. In this regard, the US government's interpretations and interpretations fall into the category of "Khoye Badrabahana Bisyar". The following lines, in the light of the views of international law experts, the relevant sections of the UN Charter and Resolutions, prove that US aggression is unjustified in all respects.

According to Oppenheim, a professor of international law, undue interference by one state in the affairs of another in order to maintain or change the status quo is in fact a "dictatorial intervention." In the words of another lawmaker, Quincy Wright, the intervention could be diplomatic or even military, a letter written in a threatening tone, warning of possible use of military force or coercive measures. (13)

Article 2 (4) of the UN Charter contains guidelines for all member states:

"All member states shall refrain from the use of force or threats against the territorial integrity or political sovereignty of any State in the conduct of its international relations. They shall not take any oath which is inconsistent with the purposes of the United Nations." "

This principle was reiterated by the United Nations General Assembly in Resolution 2131 (XX) December 1965 in the following words:

"Whatever the reason, no state has the right to interfere directly or indirectly in the internal or external affairs of another state."

In 1970, the UN General Assembly unanimously adopted a resolution reaffirming the principles of friendly relations and cooperation and non-interference between states in the light of the UN Charter.

\section{According to the resolution}

"It is the duty of every state to refrain from organizing, inciting, participating in any form of terrorism or civil war in another state or to incite organized terrorism within the territorial limits of that state. It is their duty to refrain from any action that involves the use of force or intimidation.

No one state or group of states has the right to interfere in the internal and external affairs of another state, directly or indirectly, or to interfere in any way against

${ }^{13}$ International Law: Vol. 1, Oppen Hein (P.305) its political, cultural and economic interests. Any kind of interference or alleged threat is a violation of international law. "( $\left.{ }^{14}\right)$

When Iraq invaded Kuwait in 1990, there was a backlash and emergency Security Council meetings were called. In the wake of this incident, the UN Security Council passed several resolutions. The first was Resolution 660, which called on Iraq to withdraw its forces from Kuwait immediately. Subsequently, in the light of Chapter 7 of the UN Charter, the Security Council adopted another Resolution 661, which imposed restrictions on international trade and exports with Iraq. Despite these resolutions, Iraq did not withdraw its troops from Kuwait, and the Security Council adopted Resolution 678, which formally authorized collective action. It authorized member states to "use all necessary means" to expel Iraq from Kuwait. The interesting thing about this resolution is that it does not mention any specific state that will take "necessary steps" against Iraq. However, the United States willingly assumed that it was responsible for leading this collective action. In light of the legal veil that the resolution provided, the United States led a mass military offensive in Iraq called "Operation Desert Storm."

Operation "Desert Storm" was also ended by a Security Council Resolution 687. The resolution imposed a number of conditions on Iraq, which it accepted, realizing the gravity of the situation. Since the same resolution No. 687 is cited by these two countries in defense of the latest aggression by the United States and the United Kingdom, it seems appropriate to state here some of the conditions contained in this resolution. The resolution included:

1. Establishment of a United Nations Observer Group to monitor the Kuwait-Iraq border

2. Implementation of the Geneva Protocol on Toxic Gas by Iraq

3. Destruction of chemical and biological weapons and missiles and closure of storage facilities under international supervision

4. Establishment of the UN Special Mission (UNSCOM) in the light of Article 29 of the UN Charter 5. Opening of all chemical and biological weapons stockpiles by Iraq for commission inspection 6. Iraq bans nuclear weapons from other countries and assures implementation of NPT clauses

\footnotetext{
${ }^{14}$ General Assembly Resolution No: 2625 (xxv) of October 24, 1970
} 


\section{SJIF Impact Factor: 7.001| ISI I.F.Value:1.241| Journal DOI: 10.36713/epra2016 ISSN: 2455-7838(Online) EPRA International Journal of Research and Development (IJRD)}

7. Iraq provides the International Atomic Energy Agency with a list of all nuclear facilities and AEA inspectors have the right to inspect such facilities.

Iraq accepted the terms of the ceasefire and signed it. In this way, he imposed a lot of restrictions on himself. The United States and Britain have accused Iraq of violating the terms of the resolution to launch "Operation Desert Fox". But this self-made excuse is irrational, absurd and a slap in the face of facts for the following reasons:

(1) If the latest Anglo-American aggression has been carried out in the light of UN Security Council resolutions, the Secretary-General of the United Nations, expressing his sorrow and grief, said that "the United States and Britain has demonstrated naked aggression and trampled on the sanctity of the United Nations. " He said in a very heartfelt tone:

"America's recent move will be a tragic chapter in the history of the United Nations. This barbarism has shaken the global conscience." ${ }^{15}$ )

(2) With the exception of the United States and the United Kingdom, all other permanent members of the Security Council, Russia, China and France, have strongly opposed "Operation Desert Fox," as stated by Russian President Boris Yeltsin.

"The United States and the United Kingdom have flagrantly violated the United Nations Charter, the established principles of international law and the rules of responsible conduct of states" ( $\left.{ }^{16}\right)$.

\section{France protested}

Richard Butler's report should have been presented to the Security Council first. The United States has decided to send fire and iron ore to Iraq "(17)

Russia and China have recalled their ambassadors from Washington and London in protest.

(3) No action could be taken against Iraq above the Security Council. China and Russia have stated that when the Security Council imposes its own conditions, it has the power to take action in the event of a breach of them. Approved in light of the UN Charter. No member state can take independent and unilateral action to implement any resolution. If this power is

\footnotetext{
${ }^{15}$ America ki Andhi Taqleed ki Cheera Dastyan, Daily Jang

Lahore, December, 28, 1998

${ }^{16}$ General Assembly Resolution No: 2625 (xxv) of October
}

24, 1970.

${ }^{17}$ America ki Andhi Taqleed ki Cheera Dastyan, Daily Jang

Lahore, December, 28, 1998 given to a single state, then the powerful countries will use the Security Council for their own purposes to launch aggression against the weaker countries and thus open a dangerous door of aggression.

(4) Contrary to Resolution No. 678, there is no mention in Resolution No. 687 of taking "collective action" unilaterally. Therefore, no member state has any such legal authority. Furthermore, the Collective Action mentioned in Resolution 678 was for a limited time only. When Iraq was invaded by this resolution in 1991, its purpose was fulfilled. It is not possible to take collective action again and again. UN Resolution 678, which was explicitly adopted to end Iraq's aggression against Kuwait, cannot be re-argued.

(5) As the later report proved, Unscom was involved in espionage operations in Iraq. And Richard Butler's report did not identify any serious violations by Iraq that could be punished in the form of barbaric bombings. Even if it is acknowledged that Iraq has not fully complied with UN Resolution 687, no single state has the right to assume the responsibilities of the United Nations alone. Decide against naked aggression. (6) It is a well-established principle of international law that whenever it is difficult to make a clear decision as to whether a state's action is legal or illegal, the other party will respond to determine its legal status. Is placed in front. If the reaction is against it, that action will be considered illegal. Anglo-American aggression was protested globally, as if it were unjustified and illegal in the light of international law.

The worst violations of the United States and human rights

The repetition of human rights over the past few years is unprecedented. The Universal Declaration of Human Rights, adopted by the UN General Assembly on December 10, 1948, was so exaggeratedly propagated that humanity really bowed down to the principles of equality, justice and freedom of expression. Is. The declaration was sometimes called the World Magna Carta $\left({ }^{18}\right)$, sometimes called the greatest document in the history of human aspirations, and sometimes called one of the most important documents of the twentieth century. Verbal devotion was expressed from Some have called it the "first international treaty on human rights" ${ }^{(19)}$. In the preamble to the declaration itself, it is described as a "common standard" for the desired performance of all peoples and nations. British Prime Minister Winston

\footnotetext{
${ }^{18}$ U,Thant From Burma, Ex-Sec. General of U.N. in 1960, special edition of the electronic

${ }^{19}$ Hillary Clinton: ibid (P.8)
} 


\section{SJIF Impact Factor: 7.001| ISI I.F.Value:1.241| Journal DOI: 10.36713/epra2016 ISSN: 2455-7838(Online) EPRA International Journal of Research and Development (IJRD)

Churchill called it the "coronation of human rights". The Horizontal Declaration begins with the golden letters:

"Recognizing the innate dignity of all members of the human family and their equal and inalienable rights is in fact the foundation of freedom, justice and world peace."

The words of the first article of UDHR are:

"All human beings are born free and equal in dignity and rights."

"All human beings are born free, their dignity and rights are equal" $\left({ }^{20}\right)$

The Universal Declaration was in some respects very vague and had a general impression. Therefore, the need for clarification of some of its provisions and preparation of supporting ethical and legal documents, treaties or conventions for its implementation was soon felt. By 1995, 65 such documents had come to light. Two of these documents:

"International Charter for Economic, Social and Cultural Rights" (21)

Of particular note are the International Covenant on Civil and Political Rights (22).

The two Covenants contain all the details of Article 30 of the Universal Declaration, as well as obliging member states to abide by them, and provide some additional details. The preamble to the Charter of Civil and Political Rights, among other things, emphasizes that member states will create an environment in which the goal of civil and political liberties is easily achieved. The preamble also includes a section of the UN Charter that states member states have a responsibility to uphold human rights and freedoms and promote their universal respect. The Charter is divided into six parts and is a large document consisting of a total of 53 articles. Excerpts from some of its clauses will be useful in our future discussion:

Article 1: All people have the right to selfdetermination. Based on this right, they freely determine their political status and are free to make decisions for their economic, social and cultural development.

\footnotetext{
${ }^{20}$ Winston E. Langolly, Human Rights: Sixty Major Global Instruments UDHR UNGA, Res 217 A (iii) of Dec. 10, 1948.

${ }^{21}$ International Covenant on Economic, Social and Cultural Rights, Adopted by GA Res: 2200 of Dec. 16, 1966.

${ }^{22}$ International Covenant on Civil and Political Rights, Adopted Dec. 16, 1986.
}

Article 2: Member States shall promote the right to self-determination and respect this right in the light of the United Nations Charter.

Article 6: And every human being has the birthright of life. This right will be protected in accordance with the law. No one will be deprived of life unilaterally.

In 1968, an international conference on human rights was held in Tehran to review the progress of the UDHR. At the end of the conference, the "Tehran Declaration" reiterated:

"Peace is the universal aspiration of mankind and peace and justice are essential for the full implementation of fundamental freedoms and human rights" (23).

In November 1989, the United Nations General Assembly adopted the "Declaration of the Rights of the People for Peace" (35).

1. The General Assembly reaffirms that the main objective of the United Nations is to establish international peace and security.

2. The General Assembly expresses the desire and aspiration of mankind that it is the sacred duty of every state to end war and establish a peaceful life.

The words of its Articles 1,2,3 are:

"1. The General Assembly solemnly declares that the people of our planet have a sacred right to peace.

2. Protecting and enforcing the people's right to peace is a fundamental duty of every state.

3. Practicing the right to peace requires states to formulate policies to counter the threat of war, condemn the use of force in international relations, and resolve international disputes peacefully in the light of the United Nations Charter. Solve the way."

The above declarations, charters and declarations are nothing more than a verbal deposit and word spread. The Vietnam War, the Korean War, the Russian invasion of Afghanistan, the double invasion of Iraq by allied and US forces, the cheapening of Muslim blood in Bosnia, Kosovo and Kashmir, the genocide of Rwanda and the civil war in countries like Somalia, etc. The events of 1945 are indisputable evidence that all human beings on the planet are neither "free" nor "equal". Given the colonial rivals of the United States and European countries and their discriminatory treatment of Muslims, this preaching of human rights is mere deception, deception and extreme hypocrisy. "Human rights" actually mean the rights of whites and Jews. The United States and the West are obsessed with understanding Muslims as "human beings."

The greatest human rights activist is the United States, and the fact is that no other state can match the extent to which it is violating human rights under the guise of

${ }^{23}$ Prolamation of Tehran: May, 13, 1968. 


\section{SJIF Impact Factor: 7.001| ISI I.F.Value:1.241| Journal DOI: 10.36713/epra2016 ISSN: 2455-7838(Online) EPRA International Journal of Research and Development (IJRD)}

modern colonialism, democracy, freedom and equality. For decades, US presidents have been vocal about human rights. It was started by President Jimmy Carter and since then human rights have been a constant part of US foreign policy. His meeting with the head of state is not complete without discussing the human rights situation. Ever since China cracked down on angry mobs in Tiaatman Square, the United States has had an easy excuse to criticize China, otherwise in the wake of the 1991 Gulf War and now Iraq in December 1998. The unprovoked acts of aggression against the United States are in no way comparable to China's "crime." The United States is using human rights as a weapon of psychological Cold War. He presents exaggerated reports of human rights violations to put his opponents under psychological pressure.

When Chinese President Zheng Zeman paid an official visit to the United States in 1997, President Bill Clinton expressed his concern over human rights abuses in China so frequently that he called on the Chinese president to respect the requirements of morality. The US President was forced to stand up and interrupt. Addressing Bill Clinton, he said: Mr. President! You are committing the crime of interfering in China's internal affairs, it would be appropriate for you to pay attention to the latest $\mathrm{UN}$ report on human rights in your country. " He also criticized the United States for signing 17 UN conventions, while the United States has signed only 15 such conventions. ${ }^{24}$

The first speech of the US Presidents after assuming the presidency, which they call the State of the Union Speech, has to do with listening. It is as if an angel of peace has descended from heaven who has descended from his Messiah to the children of Adam. It will cure all problems. But these same presidents are so hardhearted that their consciences do not suffer the slightest conscience while ordering the killing of millions of people.

December 10, 1998 marks the 50th anniversary of the Universal Declaration of Human Rights. President Clinton, in keeping with the glorious tradition of American presidents as usual, declared his allegiance to the sacred principles of the Declaration, calling it a great document of human history. He reminded once again in his passionate speech: "The language of the document clearly states that all human beings are born free and equal." He said: "Its principles set the standard for us. But we have to test ourselves "(25)

\footnotetext{
${ }^{24}$ The Electronic Journal, "Issues of Democracy” (P.6)

${ }^{25}$ Declaration on the Rights of people to Peace, Apvd, GA

Res. 39/11 of Nov. 12, 1984.
}

The same Bill Clinton, who was in Jerusalem just three days later, had mentally prepared for the invasion of Iraq, and then on December 16, in a televised address to Iraq, he took the nation into confidence. Justifying the barbaric attack, he said:

"Bombing was necessary to convince the world of American power" (26)

After the collapse of the Soviet Union, the United States became a unipolar superpower, as if the world was not yet aware of American power. For this, it was deemed necessary to increase its power by brutally bombing the people of a Muslim country. Even in the Gulf War, the American nation's taste for barbarism was not satisfied, in which millions of innocent Iraqi Muslims were martyred. The American president soon forgot the sacred principles he was preaching to the whole world on December 10. He has merely unveiled peace, brotherhood, justice, freedom, in fact his Genghis Khan face is what we saw once again in the recent aggression against Iraq. We are the ones who are still deceived about their authenticity. Otherwise, Allama Iqbal (may Allah have mercy on him) would have removed the veil from his face long ago.

The vision of the leaders of the Muslim Ummah has only seen their bright face, they are deprived of the insight that can see the tide of darkness behind this light. Fear of length is rampant, but he still wants the pool of colonial hypocrisy to be opened a little more: The eloquence and eloquence of Hillary Clinton, the intellectual wife of the President of the United States, who addressed a ceremony at the United Nations on December 10, 1997, is a masterpiece. And he painstakingly portrayed the painful scenes of human rights abuses around the world, from the atrocities of Nazi Germany. He did not name Islam, but did say that "in some religions, women do not have the right to half-martyrdom and divorce." But alas, not a single sentence in his heartfelt detailed speech was about the grave violation of the human rights of innocent Muslims in Iraq, Bosnia, Palestine and Kashmir. He spoke in support of the US Constitution, but said that maintaining some independence was not the answer.

"His views on the protection of human dignity were far ahead of his time when he declared that all human beings are created equal."

Hillary Clinton expressed her regret over the global human rights situation:

"Half a century later, we have not broadened the scope of human dignity. We still have many women and men

\footnotetext{
${ }^{26}$ Shafeeq ul Islam Farooqi, Iraq par Fauji Bombari aur

American Fauji Taqat, daily Nwai Waqt, January, 10, 1999
} 


\section{SJIF Impact Factor: 7.001| ISI I.F.Value:1.241| Journal DOI: 10.36713/epra2016 ISSN: 2455-7838(Online) EPRA International Journal of Research and Development (IJRD)

who are deprived of the fundamental rights enshrined in the Declaration. There are many about whom we are heartbroken. There are many whose sufferings we have failed to see, hear and feel "(27)

The heartbreak she expressed refers to other countries, not the United States. What he said about others is actually true of America and Americans. Isn't it true that after her heartfelt speech when Iraq was bombed in obedience to her husband's orders, she did not utter a single word of remorse?

On the occasion of the Silver Jubilee of the Universal Declaration of Human Rights, on September 14, 1998, the US House of Representatives and Senate passed a resolution reiterating its commitment to "the practical implementation and respect of the Universal Declaration and the agreements reached in its light." I express my sincere gratitude for using all my efforts. The resolution called on the American people to "use the Universal Declaration of Human Rights as an effective tool to promote tolerance, understanding and respect for human rights." $\left.{ }^{28}\right)$

Exactly three months after the resolution, the whole world saw the American nation's "tolerance, understanding and" respect for human rights "in Iraq.

Geraldine Ferraro served as US Representative to the United Nations Commission on Human Rights from 1994 to 1996. This is the same lady who won the vice presidential election against George W. Bush in 1988. Check out the following excerpt from his speech, which reflects the hypocrisy of the entire American nation. Says:

"It is our duty to sit in the Human Rights Commission and openly express our responsibilities to the human race. We must be heard. Our voice is the voice of the oppressed. The voice of the child who has food to eat." No, the voice of the young man who was forced to put a military gun on his shoulder, the voice of the mother who is crying because she can't feed her children, the voice of the father who is chained because he She dared to express her remorse. " $\left({ }^{29}\right)$

Geraldine and other humanitarian members of her human rights commission, who have been the "voice" of oppressed children, mothers, fathers and human beings, have not seen the millions of hungry children in Iraq who have been subjected to cruel sanctions and died blind. Went down to the cave.

Dear readers! The catastrophe that Iraqi Muslims have suffered is unimaginable. According to a UNICEF

\footnotetext{
${ }^{27}$ Issues of Democracy (P.10)

${ }^{28}$ IBID (P.27)

${ }^{29}$ IBID (P.40)
}

report, more than 350,000 children under the age of five were killed during and after the Gulf War. $\left({ }^{30}\right)$

Former United States Attorney General Ramsay Clark is one of the few Americans whose conscience has forced them to speak out against this inhumane treatment. On August 16, 1995, in Los Angeles, while addressing a large gathering, people were shocked to hear the shocking facts about the Gulf War. His speech was published in many newspapers and magazines. Here is an excerpt:

"The bombing was intended to destroy the basic needs of the human population," the Pentagon said in a statement.

"The bombing was aimed at destroying the basic needs of the human population. According to the Pentagon, 110,000 airstrikes were carried out during the 24-day war, which resulted in large reservoirs (dams), water treatment plants, land. Within four days, not a single water supply center was left intact, except for a few wells where people used to draw water by hand. Within just 30 minutes of the start of the war, 90 percent of the electricity system was shut down, destroying food sources, 90 percent of poultry within two months, 60 percent of milk and meat within four months. The animals were killed. There was no capacity to produce or import grain. There was no stockpile of grain left. Iraq imported $40 \%$ of its food and produced $60 \%$ of its own food. In the next four years, food production fell by two-thirds and 88,000 tons of ammunition were dropped on Hiroshima in just 42 days. The atomic bomb dropped on it caused seven and a half times more destruction. The bombing left Iraq unable to meet the basic needs of its population. Five million people died during the Gulf War and five years after the war. "( $\left.{ }^{(31}\right)$ (Translation: Chaudhry Muzaffar Hussain)

As of 1995, sanctions on Iraq had killed more than 500,000 Iraqi children, according to the Food and Agriculture Organization of the United Nations (FAO). Denis Holli-day, the coordinator of the post-oil food scheme in Baghdad, reports that between 5,000 and 6,000 Iraqi children die every day. He resigned, accusing UN member states of moral bankruptcy. Colin Rowat, another Cambridge native, commented on the same immoral situation:

"When Saddam Hussein was on our side, we didn't care that he was Kurdish. Now that he's our enemy, we don't

\footnotetext{
${ }^{30}$ Chaudhry Muzaffar Hussain, Niksan k Noha, Daily Jang

24 November 1997

${ }^{31}$ Ramsey Clarke, Impact International, (Vol. 25, No. 9, Sep.

1995) London UK
} 
care that innocent children are the victims of sanctions." ( $\left.{ }^{32}\right)$

The people cited in the above lines are just a handful of people whose consciences are still alive and who are capable of thinking beyond the national interest in the context of humanity, otherwise as far as the collective conscience of the American nation is concerned. By the way, he is the opposite. According to a Washington Post poll, 80 percent of Americans are in favor of bombing Iraq. ( ${ }^{33}$ )

Dear readers! This is the role of a nation that considers itself a world leader and whose government justifies its intervention in even the slightest violation of human rights in other countries. What a "beastly" role human rights activists play. You can see some highlights in the lines above. Otherwise, huge offices are needed for its details. Had there been even the slightest respect for human rights among the US President and the American people, they would never have played Holi with the blood of millions of Iraqi Muslims under the guise of teaching Kuwait's independence or Saddam Hussein a lesson. They have so much advanced technology that they can only target military bases, but they have ruthlessly targeted human populations. Their goal was to completely cripple the Iraqi people so that they could forever be a role model for the American opposition !!

Americans are proud that the United Nations was the brainchild of their former president, Franklin Roosevelt, and that the Universal Declaration of Human Rights was adopted through the efforts of his wife, Elise Roosevelt Eleaner. But what is the record of the United States in promoting human rights and international law? See the report in The Economist:

Successive American presidents have described human rights, democracy, and the rule of law as guiding values in their foreign policy. They have always used international law to defend themselves and criticize others. The United States itself has obstructed the development of international law, and its record in this regard is deplorable. Instead of setting an example, the United States has signed many human rights treaties at a time when many countries The United States ratified the Genocide Convention 40 years later, the Convention Against Racial Discrimination 26 years later, and the Charter of Social and Political Rights, the most important of which, 26 years later Only two countries have not yet ratified the Convention on the Rights of the Child: the United States and Somalia, and

\footnotetext{
${ }^{32}$ The Economist: Dec. 5. 1998

${ }^{33}$ The Economist: Dec. 5. 1998
}

the United States has added additional protections to the treaties it has ratified. In the United States, they have become obsolete. F. played a key role in setting up the tribunal to hear cases, but is now the only country among its allies to oppose a permanent International Criminal Court, despite 120 countries supporting it at a July 1998 UN conference Yes, the reason is that it wants its troops to be exempt from it and this attitude of the United States is nothing new. All US governments have used international law to discredit other nations and have refused to apply it to themselves "( $\left.{ }^{34}\right)$

In Short, Some Serbian and Rwandan leaders have been convicted by an international court of "crimes against humanity". Will UN member states be able to declare the deaths of innocent people as a result of US President Bill Clinton's unprovoked war crimes a crime against humanity and demand that they be brought before the International Court of Justice? If not, what does it mean except that world justice is still subject to the interests of powerful nations?

\footnotetext{
${ }^{34}$ The Economist: Dec. 5. 1998.
} 